\title{
Greenhouse gas emissions and reactive nitrogen releases from rice production with simultaneous incorporation of wheat straw and nitrogen fertilizer
}

\author{
Longlong Xia ${ }^{1,2}$, Yongqiu Xia ${ }^{1}$, Shutan $\mathrm{Ma}^{1,2}$, Jinyang Wang ${ }^{1}$, Shuwei Wang ${ }^{1,2}$, Wei Zhou ${ }^{1,2}$, and Xiaoyuan Yan ${ }^{1}$ \\ ${ }^{1}$ State Key Laboratory of Soil and Sustainable Agriculture, Institute of Soil Science, Chinese Academy \\ of Sciences, Nanjing 210008, China \\ ${ }^{2}$ University of Chinese Academy of Sciences, Beijing 100049, China
}

Correspondence to: Xiaoyuan Yan (yanxy@issas.ac.cn)

Received: 2 December 2015 - Published in Biogeosciences Discuss.: 18 January 2016

Revised: 29 June 2016 - Accepted: 25 July 2016 - Published: 12 August 2016

\begin{abstract}
Impacts of simultaneous inputs of crop straw and nitrogen $(\mathrm{N})$ fertilizer on greenhouse gas (GHG) emissions and $\mathrm{N}$ losses from rice production are not well understood. A 2-year field experiment was established in a rice-wheat cropping system in the Taihu Lake region (TLR) of China to evaluate the GHG intensity (GHGI) as well as reactive $\mathrm{N}$ intensity $(\mathrm{NrI})$ of rice production with inputs of wheat straw and $\mathrm{N}$ fertilizer. The field experiment included five treatments of different $\mathrm{N}$ fertilization rates for rice production: 0 (RN0), 120 (RN120), 180 (RN180), 240 (RN240), and $300 \mathrm{~kg} \mathrm{Nha}^{-1}$ (RN300, traditional N application rate in the TLR). Wheat straws were fully incorporated into soil before rice transplantation. The meta-analytic technique was employed to evaluate various $\mathrm{Nr}$ losses. Results showed that the response of rice yield to $\mathrm{N}$ rate successfully fitted a quadratic model, while $\mathrm{N}$ fertilization promoted $\mathrm{Nr}$ discharges exponentially (nitrous oxide emission, $\mathrm{N}$ leaching, and runoff) or linearly (ammonia volatilization). The GHGI of rice production ranged from 1.20 (RN240) to $1.61 \mathrm{~kg} \mathrm{CO}_{2}$ equivalent $\left(\mathrm{CO}_{2} \mathrm{eq}\right) \mathrm{kg}^{-1}$ (RN0), while NrI varied from 2.14 (RN0) to $10.92 \mathrm{~g} \mathrm{~N} \mathrm{~kg}^{-1}$ (RN300). Methane $\left(\mathrm{CH}_{4}\right)$ emission dominated the GHGI with a proportion of $70.2-88.6 \%$ due to direct straw incorporation, while ammonia $\left(\mathrm{NH}_{3}\right)$ volatilization dominated the $\mathrm{NrI}$ with proportion of $53.5-57.4 \%$. Damage costs to environment incurred by GHG and Nr releases from current rice production (RN300) accounted for 8.8 and $4.9 \%$ of farmers' incomes, respectively. Cutting $\mathrm{N}$ application rate from 300 (traditional $\mathrm{N}$ rate) to $240 \mathrm{~kg} \mathrm{~N} \mathrm{ha}^{-1}$ could improve rice yield and nitrogen
\end{abstract}

use efficiency by 2.14 and $10.30 \%$, respectively, while simultaneously reducing GHGI by $13 \%$, NrI by $23 \%$, and total environmental costs by $16 \%$. Moreover, the reduction of $60 \mathrm{~kg} \mathrm{~N} \mathrm{ha}^{-1}$ improved farmers' income by CNY $639 \mathrm{ha}^{-1}$, which would provide them with an incentive to change the current $\mathrm{N}$ application rate. Our study suggests that GHG and $\mathrm{Nr}$ releases, especially for $\mathrm{CH}_{4}$ emission and $\mathrm{NH}_{3}$ volatilization, from rice production in the TLR could be further reduced, considering the current incorporation pattern of wheat straw and $\mathrm{N}$ fertilizer.

\section{Introduction}

Rice is the staple food for the majority of the world's population. However, while it is an industry used to feed the global population, rice production is an important source of greenhouse gas (GHG) emissions and reactive nitrogen $(\mathrm{Nr})$ releases (Yan et al., 2009; Chen et al., 2014). Rice production in China involves heavy methane $\left(\mathrm{CH}_{4}\right)$ emissions due to the water regime managements (e.g., continuous flooding in some regions) and straw incorporation practices (e.g., direct incorporation without any pretreatments; Yan et al., 2009). Furthermore, lower nitrogen use efficiency for rice cultivation in China (approximately $31 \%$ ) aggravates the release of various $\mathrm{Nr}$ species, thus threatening ecosystem functions (Galloway et al., 2008; Zhang et al., 2012). Such a dilemma highlights the need for the simultaneous evaluation of GHG emissions and $\mathrm{Nr}$ losses for rice production in China. Rice 
cultivation in intensive agricultural regions, characterized by high inputs of $\mathrm{N}$ fertilizer and crop residues, should be prioritized for the implementation of such evaluation (Ju et al., 2009; Chen et al., 2014).

The Taihu Lake region (TLR) is one of the most productive areas for rice production in China, largely owing to the popularity of intensive cultivation (Zhao et al., 2012a, b). Currently, rice yield of this region in some fields can reach up to $8000 \mathrm{~kg} \mathrm{ha}^{-1}$ or even higher (Ma et al., 2013; Zhao et al., 2015). However, these grain yields are achieved with a cost to environment (Ju et al., 2009). TLR generally receives 550$600 \mathrm{~kg} \mathrm{~N} \mathrm{ha}^{-1} \mathrm{yr}^{-1}$, with the rice-growing season accounting for nearly $300 \mathrm{~kg} \mathrm{Nha}^{-1}$ (Zhao et al., 2012b). Aside from these excessive $\mathrm{N}$ inputs, TLR also experiences high amounts of crop residue incorporation, which is highly encouraged by local governments (Xia et al., 2014). However, direct straw incorporation before rice transplantation triggers substantial $\mathrm{CH}_{4}$ emissions (Ma et al., 2009, 2013). Besides such substantial releases of $\mathrm{Nr}$ and GHG in a direct way, indirect releases during the production of various agricultural materials used for farming operations are also not ignorable, due to higher input rates of these materials caused by intensive cultivation (Zhang et al., 2013; Cheng et al., 2014). This warrants the need for life-cycle assessment (LCA) of GHG emissions and $\mathrm{Nr}$ releases with respect to rice production in this region.

Considerable environmental costs can be caused by the direct and indirect releases of GHG and $\mathrm{Nr}$ from rice production in the TLR, for instance, in the form of global warming, water eutrophication, or soil acidification (Ju et al., 2009; Xia and Yan, 2011, 2012). Previous studies have proven that environmental costs assessment could provide guidance for emerging policy priorities in mitigating certain GHG or $\mathrm{Nr}$ species, after quantifying both their release amounts and damage costs to ecosystems (Gu et al., 2012). However, few studies have attempted to evaluate the total GHG and $\mathrm{Nr}$ releases and the associated environmental costs from rice production, with high inputs of $\mathrm{N}$ fertilizer and crop straw.

In the present study, we conducted 2 years of simultaneous measurements of $\mathrm{CH}_{4}$ and nitrous oxide $\left(\mathrm{N}_{2} \mathrm{O}\right)$ emissions from a rice-wheat cropping system in the TLR to evaluate the impacts of simultaneous inputs of crop straw and $\mathrm{N}$ fertilizer on (1) net global warming potential (NGWP) and GHG intensity (GHGI), (2) total $\mathrm{Nr}$ losses and $\mathrm{Nr}$ intensity (NrI), and (3) environmental costs incurred by these GHG and $\mathrm{Nr}$ releases associated with rice production, from the perspective of LCA.

\section{Materials and methods}

\subsection{Experimental site}

The field experiment was conducted in a paddy rice field at Changshu Agroecological Experimental Station $\left(31^{\circ} 32^{\prime} 93 \mathrm{~N}, 120^{\circ} 41^{\prime} 88 \mathrm{E}\right)$ in Jiangsu province, which is lo-

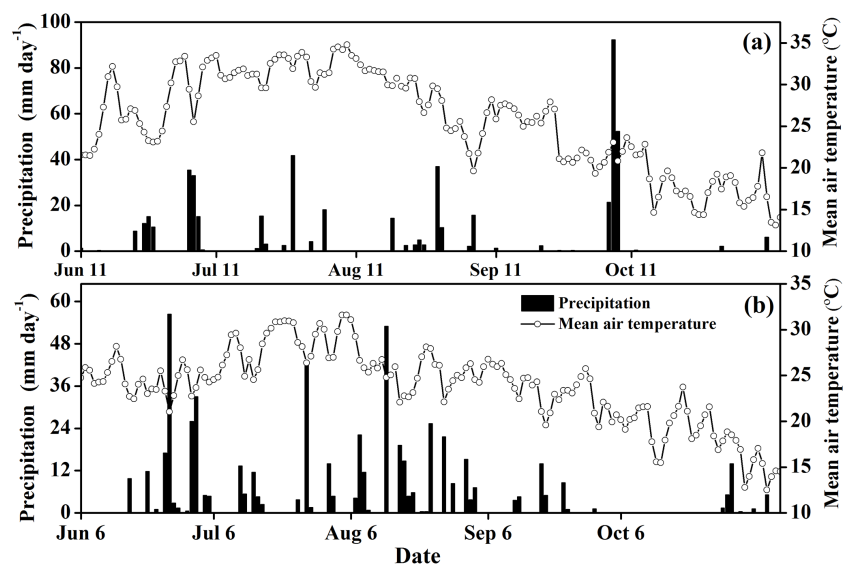

Figure 1. Seasonal variations in the daily precipitation and the temperature during the two rice-growing seasons of (a) 2013 and (b) 2014 .

cated in the TLR of China, where the cropping system is primarily dominated by summer rice (Oryza sativa L.) and winter wheat (Triticum aestivum L.) rotation. The climate of the study area is subtropical monsoon, with a mean air temperature of $16.1^{\circ} \mathrm{C}$ and mean annual precipitation of $990 \mathrm{~mm}$, of which $60-70 \%$ occurs during the rice-growing season. The daily mean temperature and precipitation during two ricegrowing seasons from 2013 to 2014 are shown in Fig. 1. The paddy soil is classified as Anthrosol, which develops from lacustrine sediments. The topsoil $(0-20 \mathrm{~cm})$ has a $\mathrm{pH}$ of 7.68 $\left(\mathrm{H}_{2} \mathrm{O}\right)$. The bulk density is $1.16 \mathrm{~g} \mathrm{~cm}^{-3}$, the organic $\mathrm{C}$ content is $20.1 \mathrm{~g} \mathrm{C} \mathrm{kg}^{-1}$, the total $\mathrm{N}$ is $1.98 \mathrm{~g} \mathrm{~kg}^{-1}$, the available $\mathrm{P}$ is $11.83 \mathrm{mg} \mathrm{kg}^{-1}$, and the available $\mathrm{K}$ is $126 \mathrm{mg} \mathrm{kg}^{-1}$.

\subsection{Experimental design and field management}

The field experiment included five treatments of different $\mathrm{N}$ fertilization rates for rice production: 0 (RN0), 120 (RN120), 180 (RN180), 240 (RN240), and $300 \mathrm{~kg} \mathrm{~N} \mathrm{ha}^{-1}$ (RN300, traditional $\mathrm{N}$ application rate in the TLR). Consistent with local practices, wheat straws were harvested, chopped, and fully incorporated into soil before rice transplantation in all treatments (Table 1). All of the treatments are laid out in a randomized block design with three replicates, and each plot

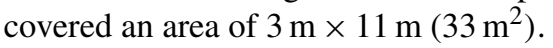

Rice is transplanted in the middle of June and harvested at the beginning of November. $\mathrm{N}$ fertilizer (in the form of urea) was split into three parts during the rice-growing season: $40 \%$ as basal fertilizer, $30 \%$ as tiller fertilizer, and $30 \%$ as panicle fertilizer. Phosphorus (in the form of calcium superphosphate) and potassium (in the form of potassium chloride) were applied as basal fertilizer at rates of $30 \mathrm{~kg} \mathrm{P}_{2} \mathrm{O}_{5} \mathrm{ha}^{-1}$ and $60 \mathrm{~kg} \mathrm{~K}_{2} \mathrm{O} \mathrm{ha}^{-1}$, respectively. All basal fertilizers were thoroughly incorporated into the soil through plowing, while topdressing fertilizers were applied evenly to the soil surface. According to local practices, a water regime was adopted 
Table 1. Field experimental treatments and agricultural management practices during the rice-growing seasons of 2013 and 2014 in the Taihu Lake region.

\begin{tabular}{lccccc}
\hline Treatment $^{\mathrm{a}}$ & RN0 & RN120 & RN180 & RN240 & RN300 \\
\hline $\begin{array}{l}\text { Chemical fertilizer } \\
\text { application rate }\end{array}$ & $0: 30: 60$ & $120: 30: 60$ & $180: 30: 60$ & $240: 30: 60$ & $300: 30: 60$ \\
$\left(\mathrm{~N}: \mathrm{P}_{2} \mathrm{O}_{5}: \mathrm{K}_{2} \mathrm{O}, \mathrm{kg} \mathrm{ha}^{-1}\right)$ & & & & & \\
Split $\mathrm{N}$ application ratio & - & $4: 3: 3$ & $4: 3: 3$ & $4: 3: 3$ & $4: 3: 3$ \\
Straw application rate (t dry matter ha & \\
Water regime & & & & & \\
Density $\left(10^{4}\right.$ plants ha $\left.^{-1}\right)$ & F-D-F-M & F-D-F-M & F-D-F-M & F-D-F-M & F-D-F-M \\
& 2.5 & 2.5 & 2.5 & 2.5 & 2.5 \\
\hline
\end{tabular}

${ }^{a}$ RN0, RN120, RN180, RN240, and RN300 represent $\mathrm{N}$ application rates of $0,120,180,240,300 \mathrm{~kg} \mathrm{Nha}^{-1}$, respectively. ${ }^{\mathrm{b}} 3.94 / 2.88$ denotes that straw application rates during the rice-growing seasons of 2013 and 2014 are 3.94 and 2.88 try matter ha $^{-1}$, respectively. ${ }^{\mathrm{c}} \mathrm{F}$, flooding; $\mathrm{D}$, mid-season drainage; $\mathrm{M}$, moist but non-waterlogged by intermittent irrigation.

with flooding followed by mid-season drainage, which is in turn followed by flooding and moist but non-waterlogged by intermittent irrigation. Details of the specific agricultural management practices for rice production are provided in Table 1 .

\subsection{Gas fluxes and topsoil organic carbon sequestration rate}

The $\mathrm{CH}_{4}$ and $\mathrm{N}_{2} \mathrm{O}$ fluxes during the rice-growing seasons of 2013 and 2014 were measured using a static chamber and gas chromatography technique. Details of the procedures used for sampling and analysis the gases are described in Xia et al. (2014).

Generally, it takes long-term observations over years to decades before the soil organic carbon (SOC) change is detectable (Yan et al., 2011). The SOC content changes in the short-term field experiment could not be correctly measured, due to the high variability in SOC during the preliminary several years of the experiment. Therefore, we used the following relationship between the straw input rate $\left(\mathrm{kgCha}^{-1} \mathrm{yr}^{-1}\right)$ and SOC sequestration rate (SOCSR, $\left.\mathrm{kg} \mathrm{Cha}^{-1} \mathrm{yr}^{-1}\right)$, obtained through an ongoing long-term straw application experiment in the same region, to calculate the SOCSR in this study (Xia et al., 2014):

SOCSR $=$ straw input rate $\times 0.0603+31.39$

$$
\left(R^{2}=0.92\right) \text {. }
$$

This ongoing long-term field experiment is also taking place at the Changshu Agroecological Experimental Station (since 1990), which includes three straw application levels: 0, $4.5 \mathrm{t}$, and $9.0 \mathrm{t}$ dry weight ha $\mathrm{h}^{-1} \mathrm{yr}^{-1}$. The Eq. (1) was established based on the results of 22 years of observation (Xia et al., 2014). Same agricultural management practices were applied to the ongoing long-term experiment and the experiment of this study.

\subsection{Net global warming potential and greenhouse gas intensity}

The net global warming potential (NGWP, $\mathrm{kg} \mathrm{CO}_{2}$ eq ha ${ }^{-1}$ ) and greenhouse gas intensity (GHGI, $\mathrm{kg} \mathrm{CO}_{2} \mathrm{eq} \mathrm{kg}^{-1}$ ) of rice production in the TLR were calculated using the following equations:

$$
\begin{aligned}
\mathrm{NGWP} & =\sum_{i=1}^{\mathrm{m}} \mathrm{AI}_{i \mathrm{co}_{2}}+\mathrm{CH}_{4} \times 25+\mathrm{N}_{2} \mathrm{O} \times 44 / 28 \\
& \times 298-\mathrm{SOCSR} \times 44 / 12, \\
\mathrm{GHGI} & =\mathrm{NGWP} / \text { rice yield, }
\end{aligned}
$$

where $\mathrm{AI}_{i \mathrm{co}_{2}}$ denotes the GHG emissions from the production and transportation of agricultural inputs, which are calculated by multiplying their application rates by their individual GHG emission factors, such as synthetic fertilizers, diesel oil, electricity, and pesticides (Liang, 2009; Zhang et al., 2013). $\mathrm{CH}_{4}\left(\mathrm{~kg} \mathrm{CH}_{4} \mathrm{ha}^{-1}\right), \mathrm{N}_{2} \mathrm{O}\left(\mathrm{kg} \mathrm{Nha}^{-1}\right)$, and SOCSR $\left(\mathrm{kg} \mathrm{Cha}^{-1} \mathrm{yr}^{-1}\right.$ ) represent the $\mathrm{CH}_{4}$ and $\mathrm{N}_{2} \mathrm{O}$ emissions from rice production and the SOC sequestration rate, respectively.

\subsection{Total $\mathrm{Nr}$ losses and $\mathrm{Nr}$ intensity}

The total $\mathrm{Nr}$ losses $\left(\mathrm{kg} \mathrm{Nha}^{-1}\right)$ and $\mathrm{Nr}$ intensity ( $\mathrm{NrI}$, $\mathrm{g} \mathrm{N} \mathrm{kg}^{-1}$ ) were calculated using the following equations:

$$
\begin{aligned}
\text { Total Nr losses } & =\sum_{i=1}^{\mathrm{m}} \mathrm{AI}_{i \mathrm{~N}_{r}} \\
& +\left(\mathrm{NH}_{3}+\mathrm{N}_{2} \mathrm{O}+\mathrm{N}_{\text {leaching }}+\mathrm{N}_{\text {runoff }}\right)_{\text {rice }} ; \\
\mathrm{NH}_{3} \text { volatilization } & =0.17 \times \mathrm{N}_{\text {rate }}+0.64, \\
\mathrm{~N} \text { runoff } & =5.39 \times \operatorname{Exp}\left(0.0054 \times \mathrm{N}_{\text {rate }}\right), \\
\mathrm{N} \text { leaching } & =1.44 \times \operatorname{Exp}\left(0.0037 \times \mathrm{N}_{\text {rate }}\right), \\
\mathrm{NrI} & =(1000 \times \text { Total } \mathrm{Nr} \text { losses }) / \text { rice yield },
\end{aligned}
$$

where $\mathrm{AI}_{i_{\mathrm{Nr}}}$ denotes the $\mathrm{Nr}$ lost (mainly through $\mathrm{N}_{2} \mathrm{O}$ and $\mathrm{NO}_{x}$ emissions) from the production and transportation of agricultural inputs (Liang, 2009; Zhang et al., 2013), while $\left(\mathrm{NH}_{3}+\mathrm{N}_{2} \mathrm{O}+\mathrm{N}_{\text {leaching }}+\mathrm{N}_{\text {runoff }}\right)_{\text {rice }}$ represents the $\mathrm{NH}_{3}$ 
volatilization, $\mathrm{N}_{2} \mathrm{O}$ emissions, $\mathrm{N}$ leaching, and runoff during the rice-growing season. $\mathrm{N}_{\text {rate }}$ represents the $\mathrm{N}$ fertilizer application rate. Nr empirical models (Eqs. 5, 6,7) are derived from a meta-analysis of published literature concerning $\mathrm{Nr}$ losses from rice production in the TLR. Specific details regarding this literature survey are provided in the Supplement.

\subsection{Total environmental costs incurred by GHG and $\mathrm{Nr}$ releases and farmers' income}

The total environmental costs $\left(\mathrm{CNY}\right.$ ha $\left.^{-1}\right)$ incurred by GHG and $\mathrm{Nr}$ releases and farmers' income from rice production in the TLR were calculated based on the following equations:

$$
\begin{aligned}
\text { Environmental costs } & =\sum_{i=1}^{n}\left(\mathrm{Nr}_{i} A \times \mathrm{DC}_{i}\right) \\
& +\mathrm{CO}_{2} A \times \mathrm{DC}_{\mathrm{CO}_{2}},
\end{aligned}
$$

Farmer's income $=$ rice yield $\times$ rice price

$$
\text { - input costs. }
$$

$\mathrm{Nr}_{i} A(\mathrm{~kg} \mathrm{~N})$ represents the release amounts of certain $\mathrm{Nr}$ species $(i)$ and $\mathrm{DC}_{i}\left(\mathrm{CNY} \mathrm{kg}{ }^{-1} \mathrm{~N}\right)$ denotes the damage cost (DC) per kg of certain $\mathrm{Nr}(i) \cdot \mathrm{CO}_{2} A(\mathrm{t})$ and $\mathrm{DC}_{\mathrm{CO}_{2}}$ $\left(\mathrm{CNY} \mathrm{t}^{-1}\right)$ represent the $\mathrm{CO}_{2}$ emissions amount and global warming cost of $\mathrm{CO}_{2}$, respectively. $\mathrm{N}_{2} \mathrm{O}$ is both a GHG and $\mathrm{Nr}$ species, but its environmental cost was calculated as a GHG here. Because the cost of $\mathrm{N}_{2} \mathrm{O}$ emission as $\mathrm{Nr}$ species is to damage human health (Gu et al., 2012), but the effects of $\mathrm{Nr}$ losses on the damage costs of human health were not included in this study. The environmental costs mainly refer to the global warming incurred by GHG emissions, soil acidification incurred by $\mathrm{NH}_{3}$ and $\mathrm{NO}_{x}$ emissions, and aquatic eutrophication caused by $\mathrm{NH}_{3}$ emissions, $\mathrm{N}$ leaching, and runoff (Xia and Yan, 2012).

\subsection{Nitrogen use efficiency and $\mathrm{N}_{2} \mathrm{O}$ emission factor}

Nitrogen use efficiency (NUE) and the $\mathrm{N}_{2} \mathrm{O}$ emission factor $\left(\mathrm{EF}_{d} \%\right)$ were respectively calculated by the following equations (Ma et al., 2013; Yan et al., 2014):

$$
\begin{aligned}
\mathrm{NUE} & =\left(U_{\mathrm{N}}-U_{0}\right) / F_{\mathrm{N}}, \\
\mathrm{EF}_{d} \% & =\left(E_{\mathrm{N}}-E_{0}\right) / F_{\mathrm{N}},
\end{aligned}
$$

where $U_{\mathrm{N}}$ is the grain $\mathrm{N}$ uptake $\left(\mathrm{kg} \mathrm{ha}^{-1}\right)$ measured in grain at physiological maturity in the $\mathrm{N}$ fertilization treatments, while $\mathrm{U}_{0}$ is the $\mathrm{N}$ uptake measured in grain in the treatment without $\mathrm{N}$ fertilizer addition (RN0). $E_{\mathrm{N}}$ denotes the cumulative $\mathrm{N}_{2} \mathrm{O}$ emissions in the $\mathrm{N}$ fertilization treatments, while $E_{0}$ denotes the $\mathrm{N}_{2} \mathrm{O}$ emissions in the RNO. $F_{\mathrm{N}}$ represents the application rate of $\mathrm{N}$ fertilizer. The $\mathrm{N}$ uptake in straw and grain was analyzed via concentrated sulfuric acid digestion and the Kjeldahl method (Zhao et al., 2015).

\subsection{Statistical analysis}

Differences in seasonal $\mathrm{CH}_{4}, \mathrm{~N}_{2} \mathrm{O}$ emissions, and rice yield of the two rice-growing seasons from 2013 to 2014 affected

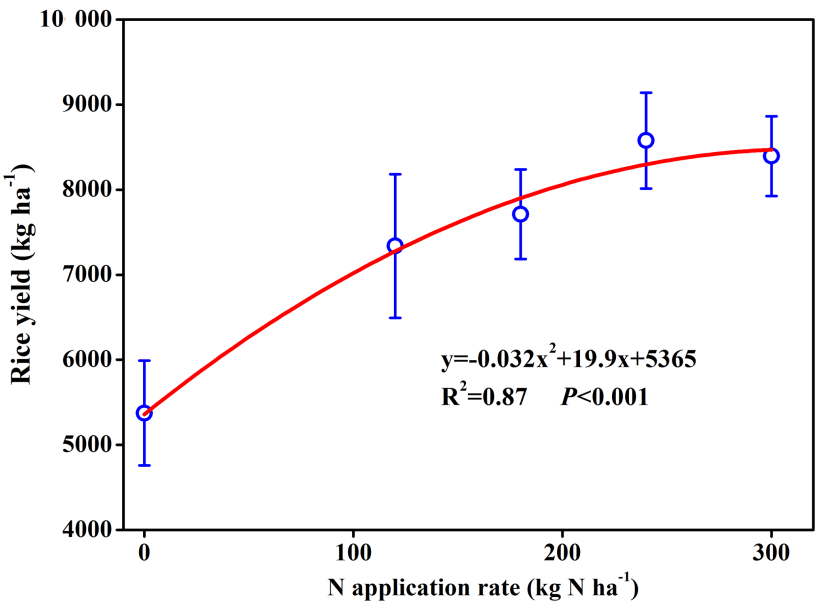

Figure 2. Relationship between $\mathrm{N}$ fertilizer application rate and average rice yield over the two rice-growing seasons of 2013 and 2014 in the Taihu Lake region. The vertical bars represent standard errors.

by fertilizer treatments, year, and their interaction were examined by using a two-way analysis of variance (ANOVA; Table 2). The grain yield, seasonal $\mathrm{CH}_{4}$, and $\mathrm{N}_{2} \mathrm{O}$ emissions, SOCSR and GHGI of different treatments were tested by ANOVA, and mean values were compared by least significant difference (LSD) at the $5 \%$ level. All these analyses were carried out using SPSS (version 19.0, USA).

\section{Results and discussion}

\subsection{Rice yield and NUE}

The two-way ANOVA analyses indicated that the rice grain yields were significantly affected by the year and fertilizer treatment (Table 2). The farmers' practice plot (RN300) had an average rice grain yield of $8395 \mathrm{~kg} \mathrm{ha}^{-1}$, with an NUE of $31.35 \%$, over the two growing seasons from 2013 to 2014 . Compared with $\mathrm{RN} 300$, reducing the $\mathrm{N}$ fertilizer rate by $20 \%$ (RN240) slightly improved the grain yield and NUE to $8576 \mathrm{~kg} \mathrm{ha}^{-1}$ and $34.58 \%$, respectively. Further $\mathrm{N}$ reduction, without additional agricultural managements, could decrease the rice yield by $8.15 \%$ (RN180) and $15.18 \%$ (RN120; Table 3). The response of rice yield to the synthetic $\mathrm{N}$ application rate in our study successfully fitted a quadratic model (Fig.2), as has been reported in previous studies (Xia and Yan, 2012; Cui et al., 2013a). Reducing $\mathrm{N}$ application reasonably, therefore, is considered essential to reduce environmental costs, without sacrificing grain yield (Chen et al., 2014). Our study showed that lowering the $\mathrm{N}$ input adopted by local farmer $\left(300 \mathrm{~kg} \mathrm{~N} \mathrm{ha}^{-1}\right)$ by $20 \%$ could still enhance the grain yield and NUE. However, a further reduction of $\mathrm{N}$ by $40 \%$ (RN180) would largely impair the rice yield (Table 3).

Further reduction in $\mathrm{N}$ fertilizer may be achieved with improvements of agricultural managements. Ju et al. (2009) 
Table 2. Two-way ANOVA for the effects of fertilizer (F) application and year ( $\mathrm{Y}$ ) on $\mathrm{CH}_{4}$ and $\mathrm{N}_{2} \mathrm{O}$ emissions, and rice grain yields in rice paddies.

\begin{tabular}{|c|c|c|c|c|c|c|c|c|c|c|}
\hline \multirow[b]{2}{*}{ Factor } & \multirow[b]{2}{*}{$\mathrm{d} f$} & \multicolumn{3}{|c|}{$\mathrm{CH}_{4}\left(\mathrm{~kg} \mathrm{ha}^{-1}\right)$} & \multicolumn{3}{|c|}{$\mathrm{N}_{2} \mathrm{O}\left(\mathrm{kg} \mathrm{Nha}^{-1}\right)$} & \multicolumn{3}{|c|}{ Yield $\left(\mathrm{kg} \mathrm{ha}^{-1}\right)$} \\
\hline & & SS & $\mathrm{F}$ & $\mathrm{P}$ & SS & $\mathrm{F}$ & $\mathrm{P}$ & SS & $\mathrm{F}$ & $\mathrm{P}$ \\
\hline $\mathrm{F}$ & 4 & 8739 & 0.79 & 0.55 & 0.33 & 12.46 & $<0.01$ & 39297547 & 32.96 & $<0.01$ \\
\hline Y & 1 & 4492 & 1.62 & 0.22 & 0.11 & 16.41 & $<0.01$ & 2810414 & 9.43 & $<0.01$ \\
\hline $\mathrm{F} \times \mathrm{Y}$ & 4 & 2532 & 0.23 & 0.92 & 0.18 & 7.1 & $<0.01$ & 750639 & 0.63 & 0.65 \\
\hline Model & 9 & 15763 & 0.63 & 0.77 & 0.62 & 10.52 & $<0.01$ & 42858600 & 15.97 & $<0.01$ \\
\hline Error & 16 & 20 & & & 0.13 & & & 5962260 & & \\
\hline
\end{tabular}

Table 3. Rice yield and nitrogen use efficiency (NUE) for the two rice-growing seasons from 2013 to 2014 in the Taihu Lake region.

\begin{tabular}{lllr}
\hline Year & Treatment $^{\mathrm{a}}$ & $\begin{array}{l}\text { Yield } \\
\left(\mathrm{kg} \mathrm{ha}^{-1}\right)\end{array}$ & $\begin{array}{r}\text { NUE } \\
(\%)\end{array}$ \\
\hline 2013 & RN0 & $4829 \pm 207$ & - \\
& RN120 & $7079 \pm 645$ & 23.40 \\
& RN180 & $7655 \pm 601$ & 28.12 \\
& RN240 & $8273 \pm 569$ & 33.61 \\
& RN300 & $8029 \pm 101$ & 30.63 \\
& RN0 & $5919 \pm 131$ & - \\
& RN120 & $7598 \pm 1077$ & 23.86 \\
& RN180 & $7768 \pm 570$ & 21.19 \\
& RN240 & $8880 \pm 435$ & 35.54 \\
& RN300 & $8761 \pm 369$ & 32.07 \\
Two-year average & RN0 & $5374 \pm 617 \mathrm{~d}^{\mathrm{b}}$ & - \\
& RN120 & $7339 \pm 843 \mathrm{c}$ & 23.63 \\
& RN180 & $7711 \pm 527 \mathrm{bc}$ & 24.66 \\
& RN240 & $8576 \pm 562 \mathrm{a}$ & 34.58 \\
& RN300 & $8395 \pm 468 \mathrm{ab}$ & 31.35
\end{tabular}

a Definitions of the treatment codes are given in the footnotes of Table 1.

b Mean \pm SD; different letters within the same column indicate a significant difference at $p<0.05$.

reported that, based on knowledge-based $\mathrm{N}$ managements, such as optimizing $\mathrm{N}$ fertilizer source, rate, timing, and place (in accordance with crop demand), rice grain yield in the TLR was not significantly affected by a 30-60\% N saving, while various Nr losses would experience a two-fold curbing. Similarly, Zhao et al. (2015) found that the NUE could be improved from 31 to $44 \%$, even under a $\mathrm{N}$ reduction of $25 \%$ for rice production in the TLR, through the implementation of integrated soil-crop system managements. In the present study, the NUE was improved by 10 via a $20 \% \mathrm{~N}$ reduction, but it still falls behind the NUE values in the studies which received knowledge-based $\mathrm{N}$ managements. Previous studies have proven that straw incorporation exerted little impacts on grain yield. For instance, a meta-analysis conducted by Singh et al. (2005) found that incorporation of crop straw produced no significant trend in improving crop yield in rice-based cropping systems. Moreover, based on a long-term straw incorporation experiment established in 1990 in the TLR, Xia et al. (2014) reported that long-term incorporation of wheat straw only increased the rice yield by $1 \%$. Therefore, in the present study, the effects of straw incorporation on rice yield were considered inappreciable.

\section{2 $\mathrm{CH}_{4}, \mathrm{~N}_{2} \mathrm{O}$ emissions and SOSCR}

Over the two rice-growing seasons from 2013 to 2014, all treatments showed similar patterns of $\mathrm{CH}_{4}$ fluxes, albeit with large interannual variation (Fig. 3a). The seasonal average $\mathrm{CH}_{4}$ emissions from all plots showed no significant difference, ranging from $289.53 \mathrm{~kg} \mathrm{CH}_{4} \mathrm{ha}^{-1}$ in the RN180 plot to $334.61 \mathrm{~kg} \mathrm{CH}_{4} \mathrm{ha}^{-1}$ in the RN120 plot (Table 4), much higher than observations conducted in the same region (Zou et al., 2005; Ma et al., 2013). This phenomenon can be attributed to the larger amounts of straw incorporation in this study (Table 1). Relative to the $\mathrm{RN} 300$ plot, $\mathrm{CH}_{4}$ emissions from the RN240 plot decreased by 8 and $10 \%$, during the rice-growing season of 2013 and 2014, respectively, although this effect was not statistically significant (Table 4).

Many studies have shown a clear linear relationship between $\mathrm{CH}_{4}$ emissions and the amounts of applied organic matter (OM; Shang et al., 2011; Xia et al., 2014). It is possible that the linear response of $\mathrm{CH}_{4}$ emissions to OM inputs can become flat or even unobvious (Fig. S1 in the Supplement) when the OM application rates among different treatments were insignificant different (Table S1 in the Supplement). It is unsurprising that no obvious relationship between $\mathrm{CH}_{4}$ emissions and $\mathrm{N}$ fertilizer application rates was observed in this study (Fig. S1), because the effects of $\mathrm{N}$ fertilization on $\mathrm{CH}_{4}$ production, transportation, and oxidation are complex. For instance, $\mathrm{N}$ fertilization can provide methanogens with more carbon substrates in the rhizosphere of plants by stimulating the growth of rice biomass, thus promoting $\mathrm{CH}_{4}$ production and transportation (Zou et al., 2005; Banger et al., 2012). On the other hand, $\mathrm{N}$ enrichment could also enhance the activities of methanotrophs, therefore enhancing $\mathrm{CH}_{4}$ oxidation (Xie et al., 2010; Yao et al., 2013).

The $\mathrm{N}_{2} \mathrm{O}$ fluxes were sporadic and pulse-like, and these fluxes showed large variations between different seasons, and the majority of the $\mathrm{N}_{2} \mathrm{O}$ peaks occurred after the application of $\mathrm{N}$ fertilizer (Fig. 3b). The two-way ANOVA analyses in- 
Table 4. The net global warming potential (NGWP) and greenhouse gas intensity (GHGI) for the two rice-growing seasons from 2013 to 2014 in the Taihu Lake region.

\begin{tabular}{|c|c|c|c|c|c|c|c|c|c|}
\hline \multirow[b]{2}{*}{ Year } & \multirow[b]{2}{*}{ Treatment $^{\mathrm{a}}$} & \multirow{2}{*}{$\begin{array}{l}\mathrm{CH}_{4} \text { emission } \\
\mathrm{kg} \mathrm{CH}_{4} \mathrm{ha}^{-1}\end{array}$} & \multirow{2}{*}{$\begin{array}{c}\mathrm{N}_{2} \mathrm{O} \text { emission } \\
\mathrm{kg} \mathrm{N} \mathrm{ha}^{-1}\end{array}$} & \multirow[b]{2}{*}{$\mathrm{kgCha}^{-1} \mathrm{yr}^{-1}$} & Irrigation & $\begin{array}{l}\mathrm{N} \text { fertilizer } \\
\text { production }\end{array}$ & Others & NGWP & GHGI \\
\hline & & & & & \multicolumn{3}{|c|}{$\mathrm{kgCO}_{2}$ eq ha $^{-1}$} & \multicolumn{2}{|r|}{$\mathrm{kgCO}_{2}$ eq kg ${ }^{-1}$} \\
\hline \multirow[t]{5}{*}{2013} & RNO & $306.07 \pm 41^{\mathrm{b}}$ & $0.08 \pm 0.01$ & 129.58 & 1170 & 0 & 217 & 8601 & 1.78 \\
\hline & RN120 & $317.26 \pm 92$ & $0.10 \pm 0.01$ & 154.07 & 1170 & 996 & 265 & 9845 & 1.39 \\
\hline & RN180 & $287.8 \pm 12$ & $0.13 \pm 0.01$ & 171.54 & 1170 & 1494 & 277 & 9568 & 1.25 \\
\hline & RN240 & $273.27 \pm 36$ & $0.14 \pm 0.06$ & 185.50 & 1170 & 1992 & 291 & 9670 & 1.17 \\
\hline & RN300 & $305.13 \pm 90$ & $0.16 \pm 0.03$ & 196.87 & 1170 & 2490 & 285 & 10927 & 1.36 \\
\hline \multirow[t]{5}{*}{2014} & RNO & $307.22 \pm 47$ & $0.02 \pm 0.05$ & 129.58 & 1256 & 0 & 240 & 8711 & 1.47 \\
\hline & RN120 & $351.96 \pm 28$ & $0.09 \pm 0.02$ & 154.07 & 1256 & 996 & 276 & 10805 & 1.42 \\
\hline & RN180 & $291.25 \pm 18$ & $0.24 \pm 0.04$ & 171.54 & 1256 & 1494 & 280 & 9795 & 1.26 \\
\hline & RN240 & $317.65 \pm 28$ & $0.34 \pm 0.12$ & 185.50 & 1256 & 1992 & 303 & 10972 & 1.24 \\
\hline & RN300 & $343.8 \pm 61$ & $0.53 \pm 0.21$ & 196.87 & 1256 & 2490 & 301 & 12169 & 1.39 \\
\hline \multirow{5}{*}{$\begin{array}{l}\text { Two-year } \\
\text { average }\end{array}$} & RNO & $306.65 \pm 39 a$ & $0.05 \pm 0.05 b$ & $129.58 \mathrm{c}$ & 1213 & 0 & 229 & 8656 & $1.61 \pm 0.25 \mathrm{a}$ \\
\hline & RN120 & $334.61 \pm 64 \mathrm{a}$ & $0.09 \pm 0.02 b$ & $154.07 \mathrm{bc}$ & 1213 & 996 & 271 & 10322 & $1.40 \pm 0.16 b$ \\
\hline & RN180 & $289.53 \pm 14 \mathrm{a}$ & $0.18 \pm 0.07 \mathrm{ab}$ & $171.54 \mathrm{ab}$ & 1213 & 1494 & 279 & 9679 & $1.25 \pm 0.09 b c$ \\
\hline & RN240 & $295.46 \pm 38 \mathrm{a}$ & $0.24 \pm 0.14 \mathrm{ab}$ & $185.50 \mathrm{ab}$ & 1213 & 1992 & 297 & 10321 & $1.20 \pm 0.08 \mathrm{~cd}$ \\
\hline & RN300 & $324.47 \pm 72 \mathrm{a}$ & $0.35 \pm 0.25 \mathrm{a}$ & $196.87 \mathrm{a}$ & 1213 & 2490 & 293 & 11550 & $1.38 \pm 0.21 b c$ \\
\hline
\end{tabular}

${ }^{\text {a }}$ Definitions of treatment codes are given in the footnotes of Table $1 .{ }^{\mathrm{b}}$ Mean $\pm \mathrm{SD}$; different letters within same column indicate a significant difference at $p<0.05$.

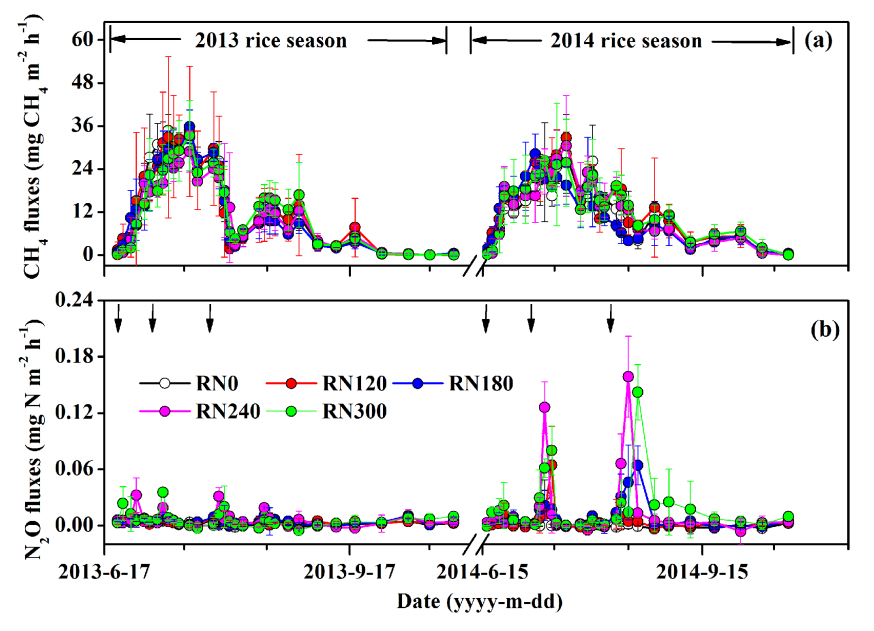

Figure 3. Seasonal variations in (a) $\mathrm{CH}_{4}$ and (b) $\mathrm{N}_{2} \mathrm{O}$ fluxes during the two rice-growing seasons from 2013 to 2014 in the Taihu Lake region. The arrow indicates $\mathrm{N}$ fertilizer application. The vertical bars represent standard errors.

dicated that the seasonal $\mathrm{N}_{2} \mathrm{O}$ emissions were significantly affected by the year, the fertilizer treatment, and their interactions during the rice-growing seasons (Table 2). The average $\mathrm{N}_{2} \mathrm{O}$ emission during the two rice-growing seasons ranged from $0.05 \mathrm{~kg} \mathrm{Nha}^{-1}$ for RN0 to $0.35 \mathrm{~kg} \mathrm{Nha}^{-1}$ for RN300 (Table 4), which increased exponentially as the $\mathrm{N}$ fertilizer rate increased; this shows that the reduction in $\mathrm{N}$ fertilizer rate is an effective approach to reduce the $\mathrm{N}_{2} \mathrm{O}$ emissions (Zou et al., 2005; Zhang et al., 2012). The average $\mathrm{N}_{2} \mathrm{O}$ emission factors varied between 0.03 and $0.1 \%$, with an average of $0.07 \%$, which is comparable with previous studies $(0.05-$
$0.1 \%$ ) conducted in the same region (Ma et al., 2013; Zhao et al., 2015).

The rice paddies have witnessed an increase in the SOC stock as a result of straw incorporation (Table 4). The estimated topsoil $(0-20 \mathrm{~cm})$ SOCSR varied from 0.13 for the RN0 plot to $0.197 \mathrm{t} \mathrm{Cha}^{-1} \mathrm{yr}^{-1}$ for the RN300 plot. The empirical model established through a long-term straw incorporation study in the same region was employed to evaluate the SOCSR in this study, which likely brought uncertainty into the results of this study. Under the same agricultural managements, soil and climatic conditions, cropping systems, and straw types, it is reasonable to believe that the rates of straw C stabilizing into SOC (i.e., conversion efficiency of crop residue $\mathrm{C}$ into SOC) are similar between these two experiments (Mandal et al., 2008). It is reported that the conversion rates of crop straw to SOC in two main wheat/maize production regions in China, which have similar climatic conditions and agricultural practices, were very close, at 40.524 vs. $40.607 \mathrm{~kg} \mathrm{SOC}^{-\mathrm{C} \mathrm{t}^{-1}}$ dry-weight straw (Lu et al., 2009). Moreover, the current estimated SOCSR for rice production in the TLR $\left(0.197 \mathrm{tC} \mathrm{ha}^{-1}\right)$ is comparable to the estimation of $0.17 \mathrm{t} \mathrm{Cha}^{-1} \mathrm{yr}^{-1}$ from Ma et al. (2013) in a study based on a paddy field experiment with OM incorporation in the same region. Therefore, we hold the opinion that the above SOCSR calculation method is appropriate, and the uncertainty incurred by this method unlikely affects the main conclusions of this study.

The magnitude of the SOC increase is variable depending on the straw incorporation method, the degree of tillage, the cropping systems, etc. (Yan et al., 2011; Huang et al., 2013). Liu et al. (2014) suggested that straw incorporation in ricebased cropping systems requires an overall consideration, due to the direct incorporation promoting substantial $\mathrm{CH}_{4}$ 
emissions. When converting to $\mathrm{CO}_{2}$ eq, the SOCSR only offsets the $\mathrm{CH}_{4}$ emissions by $6.2-9.2 \%$ in this study (Table 4). This proportion is expected to increase provided that appropriate straw incorporation method (e.g., compost straw before incorporation) and conservative tillage are adopted. Moreover, previous studies have shown that the combined adoption of conservative-tillage system with straw return had large advantages in increasing SOC stocks while reducing $\mathrm{CH}_{4}$ emissions (Zhao et al., 2015a, b).

\subsection{NGWP and GHGI}

The average NGWP for all treatments varied from 8656 to $11550 \mathrm{~kg} \mathrm{CO}_{2}$ eq ha $^{-1}$ (Table 4). $\mathrm{CH}_{4}$ emissions dominated the NGWP in all treatments, with the proportion ranging from $70.23 \%$ to $88.56 \%$, while synthetic $\mathrm{N}$ fertilizer production was the secondary contributor (Table 4). In addition, SOC sequestration offset the positive GWP by 5.18$6.18 \%$ in the fertilization treatments. Compared to conventional practice (RN300), the NGWP in the $20 \%$ reduction $\mathrm{N}$ practice (RN240) decreased by $10.64 \%$. Therein, $6.28 \%$ came from $\mathrm{CH}_{4}$ reduction and $4.31 \%$ from $\mathrm{N}$ production savings (Table 4). The GHGI of rice production ranged from 1.20 (RN240) to 1.61 (RN0) $\mathrm{kg} \mathrm{CO}_{2} \mathrm{eq} \mathrm{kg}^{-1}$, which is higher than previous estimation of $0.24-0.74 \mathrm{~kg} \mathrm{CO}_{2} \mathrm{eq} \mathrm{kg}^{-1}$ for rice production in other rice-upland crop rotation systems (Qin et al., 2010; Ma et al., 2013). Moreover, the GHGI of current rice production in the TLR (RW300) was estimated to be 1.45 times that of the national average value estimated by Wang et al. (2014a), at 1.38 vs. $0.95 \mathrm{~kg} \mathrm{CO}_{2} \mathrm{eq} \mathrm{kg}^{-1}$.

Such a phenomenon was attributed to the following reasons. First, compared to above studies, current higher amounts of direct straw incorporation (2.9-6.2 $t$ dry matter $\mathrm{ha}^{-1}$ ), before rice transplantation in the TLR, triggered substantial $\mathrm{CH}_{4}$ emissions (290-335 $\mathrm{kg} \mathrm{CH}_{4} \mathrm{ha}^{-1}$ ). Crop residue incorporation is regarded as a win-win strategy to benefit food security and mitigate climate change, due to the fact that it possesses a large potential for carbon sequestration (Lu et al., 2009). However, the GWP of straw-induced $\mathrm{CH}_{4}$ emissions was reported to be 3.2-3.9 times that of the straw-induced SOCSR, which indicates that direct straw incorporation in paddy soils worsens rather than mitigates climate changes, in terms of GWP (Xia et al., 2014). The SOC sequestration induced by straw incorporation only offset the positive GWP by $5.2-6.2 \%$ in this study. Sensible methods of straw incorporation should therefore be developed to reduce the substantial $\mathrm{CH}_{4}$ emissions without compromising the build-up of SOC stock in the TLR.

Second, the high $\mathrm{N}$ application rate $\left(300 \mathrm{~kg} \mathrm{Nha}^{-1}\right)$ in the TLR combined with the large emission factor of $\mathrm{N}$ fertilizer production, $8.3 \mathrm{~kg} \mathrm{CO}_{2} \mathrm{eq} \mathrm{kg}^{-1} \mathrm{~N}$ (Zhang et al., 2013), marked the sector of $\mathrm{N}$ fertilizer production as the secondary contributor to the GHGI (Table 4); this sector, however, was not involved in above-mentioned studies. Compared to local farmers' practices (RN300), reducing the $\mathrm{N}$ rate by $20 \%$
(RN240) lowered the GHGI by $13 \%$, under the condition of straw incorporation, although this effect was not statistically significant (Table 4). Compared to RN240, however, further reduction of N rate (RN180 or RN120) increased the GHGI, due to the fact that rice yield was considerably reduced under excessive $\mathrm{N}$ reduction. Therefore, the joint application of reasonable $\mathrm{N}$ reduction and a judicious method of straw incorporation would be promising in reducing the GHGI for rice production in the TLR, in consideration of the current situation of simultaneous high inputs of $\mathrm{N}$ fertilizer and wheat straw.

\subsection{Various Nr losses and NrI}

The results of the meta-analysis indicated that $\mathrm{N}_{2} \mathrm{O}$ emissions, as well as $\mathrm{N}$ leaching and runoff, increased exponentially with an increase in $\mathrm{N}$ application rate (Fig. $4 \mathrm{~b}$ $\mathrm{d}, P<0.01$ ), while the response of $\mathrm{NH}_{3}$ volatilization to $\mathrm{N}$ rates fitted the linear model best (Fig. $4 \mathrm{a}, P<0.01$ ). The estimated total $\mathrm{Nr}$ losses for all treatments varied from 39.3 to $91.7 \mathrm{~kg} \mathrm{Nha}^{-1}$ in the fertilization treatments (Table 5), accounting for $30.1-32.8 \%$ of $\mathrm{N}$ application rates. $\mathrm{NH}_{3}$ volatilization dominated the $\mathrm{NrI}$, with the proportion ranging from 53.5 to $57.4 \%$, mainly because of the current fertilizer application method (soil surface broadcast) and high temperatures in the field (Zhao et al., 2012b; Li et al., 2014). $\mathrm{N}$ runoff was the second most important contributor (Table 5). Using ${ }^{15} \mathrm{~N}$ micro-plots combined with 3 -year field measurements, Zhao et al. (2012b) reported that the total $\mathrm{Nr}$ losses from rice production in the TLR, under an $\mathrm{N}$ rate of $300 \mathrm{~kg} \mathrm{Nha}^{-1}$, were $98 \mathrm{~kg} \mathrm{Nha}^{-1}$, which is comparable with our estimation of $91.69 \mathrm{~kg} \mathrm{Nha}^{-1}$ in the RN300 plot. Similarly, Xia and Yan (2011) estimated the Nr losses for life-cycle rice production in this region to be around $90 \mathrm{~kg} \mathrm{~N} \mathrm{ha}^{-1}$. The high proportion $(30.1-32.8 \%)$ of the applied $\mathrm{N}$ fertilizer released as $\mathrm{Nr}$ from rice production in the TLR highlights the need to adopt reasonable $\mathrm{N}$ managements to increase the plant $\mathrm{N}$ uptake and reduce $\mathrm{Nr}$ losses (Ju et al., 2009).

The NrI of rice production in different plots varied between 2.14 (RN0) and $10.92 \mathrm{~g} \mathrm{~N} \mathrm{~kg}^{-1}$ (RN300), which increased significantly as the $\mathrm{N}$ fertilizer rate increased (Table 5). The NrI for rice production in the TLR was estimated to be $10.92 \mathrm{~g} \mathrm{~N} \mathrm{~kg}^{-1}$ (RN300), which is $68 \%$ higher than the national average value estimated by Chen et al. (2014), as a result of higher $\mathrm{N}$ fertilizer input in the TLR. Under the condition of straw incorporation, reducing $\mathrm{N}$ application rate by $20 \%$ pulled the NrI down to $8.42 \mathrm{~g} \mathrm{~N} \mathrm{~kg}^{-1}$ (RN240; Table 5). Additional $\mathrm{N}$ reduction could further lower the NrI, but the rice yield would be largely compromised (Table 3 ). Previous studies have proven that direct incorporation of crop straw had insignificant effects on various $\mathrm{Nr}$ releases (Xia et al., 2014). Because the majority of $\mathrm{N}$ contained in the crop straw is not easily degraded by microorganisms in a short-term period, and can be stabilized in soil in a long-term period, rather 
Table 5. The seasonal average reactive N (Nr) losses and reactive N intensity (NrI) for the two rice-growing seasons from 2013 to 2014 in the Taihu Lake region.

\begin{tabular}{lrrrrrrr}
\hline & $\begin{array}{r}\mathrm{NH}_{3} \\
\text { volatilization }\end{array}$ & $\begin{array}{r}\mathrm{N} \\
\text { runoff }\end{array}$ & $\begin{array}{r}\mathrm{N} \\
\text { leaching }\end{array}$ & $\begin{array}{r}\mathrm{N}_{2} \mathrm{O} \\
\text { emission }\end{array}$ & $\begin{array}{r}\mathrm{NO}_{x} \\
\text { emission }\end{array}$ & $\begin{array}{r}\text { Total Nr } \\
\text { losses }\end{array}$ & \multirow{2}{*}{$\mathrm{NrI}$} \\
\cline { 2 - 7 } Treatment $^{\mathrm{a}}$ & \multicolumn{7}{c}{$\mathrm{kg} \mathrm{Nha}^{-1}$} \\
\hline RN0 & 0.64 & 5.39 & 1.44 & 0.07 & 3.96 & 11.50 & 2.14 \\
RN120 & 21.04 & 10.30 & 2.24 & 0.12 & 5.62 & 39.32 & 5.36 \\
RN180 & 31.24 & 14.25 & 2.80 & 0.21 & 6.44 & 54.93 & 7.12 \\
RN240 & 41.44 & 19.70 & 3.50 & 0.27 & 7.26 & 72.17 & 8.42 \\
RN300 & 51.64 & 27.24 & 4.37 & 0.38 & 8.07 & 91.69 & 10.92 \\
\hline
\end{tabular}

a Definitions of treatment codes are given in the footnotes of Table 1.

Table 6. The economic indicators (two-season average) for rice production of the growing seasons from 2013 to 2014 in the Taihu Lake region (unit: $\mathrm{CNY} \mathrm{ha}^{-1}$ ).

\begin{tabular}{|c|c|c|c|c|c|}
\hline \multirow[t]{2}{*}{ Treatment $^{\mathrm{a}}$} & \multirow[t]{2}{*}{$\begin{array}{r}\text { Yield } \\
\text { income }^{b}\end{array}$} & \multirow[t]{2}{*}{$\begin{array}{l}\text { Input } \\
\text { costs }^{c}\end{array}$} & \multirow[t]{2}{*}{$\begin{array}{l}\text { Farmer's } \\
\text { income }^{\mathrm{d}}\end{array}$} & \multicolumn{2}{|c|}{ Environmental costs $\mathrm{e}$} \\
\hline & & & & GHG emissions & Nr releases \\
\hline RNO & 16125 & 4493 & 11632 & 1143 & 71 \\
\hline RN120 & 22020 & 6104 & 15916 & 1363 & 376 \\
\hline RN180 & 23130 & 6542 & 16588 & 1278 & 535 \\
\hline RN240 & 25725 & 7277 & 18448 & 1362 & 700 \\
\hline RN300 & 25185 & 7385 & 17800 & 1525 & 874 \\
\hline
\end{tabular}

than being released as various $\mathrm{Nr}$ (Huang et al., 2004; Xia et al., 2014). For instance, a meta-analysis, integrating 112 scientific assessments of the crop residue incorporation on the $\mathrm{N}_{2} \mathrm{O}$ emissions, has reported that the practice exerted no statistically significant effect on the $\mathrm{N}_{2} \mathrm{O}$ releases (Shan and Yan, 2013). Therefore, the effects of wheat straw incorporation on various $\mathrm{Nr}$ losses were considered negligible in this study.

Extra attention should be paid to the interrelationship between the NrI and GHGI, which could provide clues for the purpose of mitigation. For instance, $\mathrm{N}$ fertilizer production and application is an intermediate link between the $\mathrm{NrI}$ and GHGI (Chen et al., 2014). For the NrI, N fertilization promotes various $\mathrm{Nr}$ releases, exponentially or linearly (Fig. 4), while $\mathrm{N}$ production and application made a secondary contribution to the GHGI (Table 4). Such interrelationships ought to be taken into account fully for any mitigation options pursued in order to reduce the GHG emissions and $\mathrm{Nr}$ discharges from rice production simultaneously (Cui et al., 2013b; Cui et al., 2014).

\subsection{Economic evaluations of GHG emissions and $\mathrm{Nr}$ releases and their mitigation potential}

The total environmental costs associated with the GHG emissions and Nr releases varied from CNY $1214 \mathrm{ha}^{-1}$ for the RN0 to CNY $2399 \mathrm{ha}^{-1}$ for the RN300, which approximately accounted for $10.44-13.47 \%$ of the farmers' income and $27.05-32.47 \%$ of the input costs (Table 6). $\mathrm{CH}_{4}$ emission and $\mathrm{NH}_{3}$ volatilization were the dominant contributors to the total environmental costs (Table 4 and Fig. 5). The total damage costs to environment accounted for $13.5 \%$ of farmers' income under the current rice production in the TLR (RN300). Cutting the $\mathrm{N}$ rate from 300 to $240 \mathrm{~kg} \mathrm{~N} \mathrm{ha}^{-1}$ slightly improved the farmers' income by $3.64 \%$, while further $\mathrm{N}$ reduction would reduce the economic return of farmers (Table 6).

GHG and $\mathrm{Nr}$ releases from rice production in the TLR are expected to possess a large potential for mitigation, due to the current situation of direct straw incorporation and higher $\mathrm{N}$ fertilizer inputs. Compared to traditional practice, a reduction of $\mathrm{N}$ application rate from 300 to $240 \mathrm{~kg} \mathrm{Nha}^{-1}$ could alleviate $12.52 \%$ for GHGI (Table 4), $22.94 \%$ for NrI 

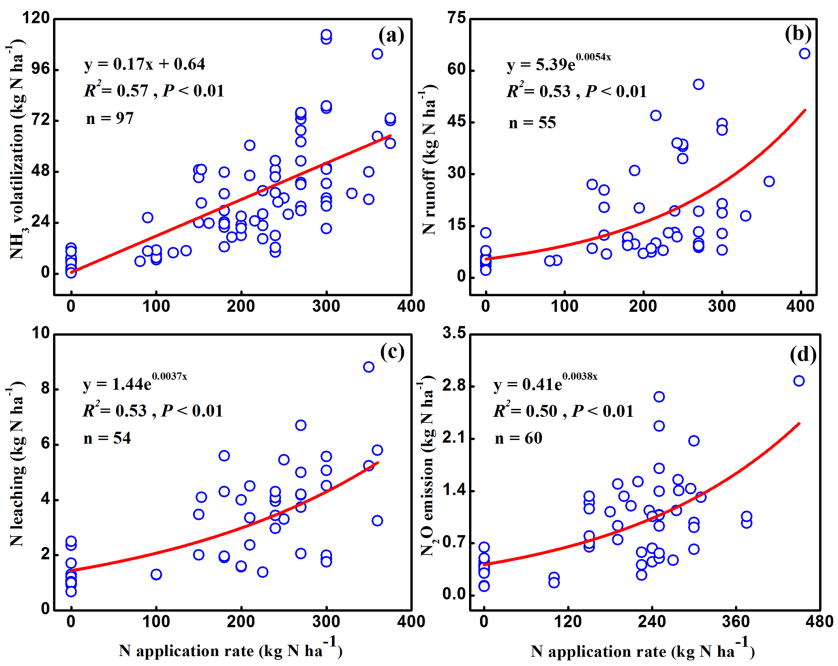

Figure 4. Relationship between $\mathrm{N}$ fertilizer application rate and (a) $\mathrm{NH}_{3}$ volatilization, (b) $\mathrm{N}$ runoff, (c) $\mathrm{N}$ leaching, and (d) $\mathrm{N}_{2} \mathrm{O}$ emissions for rice production in the Taihu Lake region. These relationships were obtained through a meta-analysis.

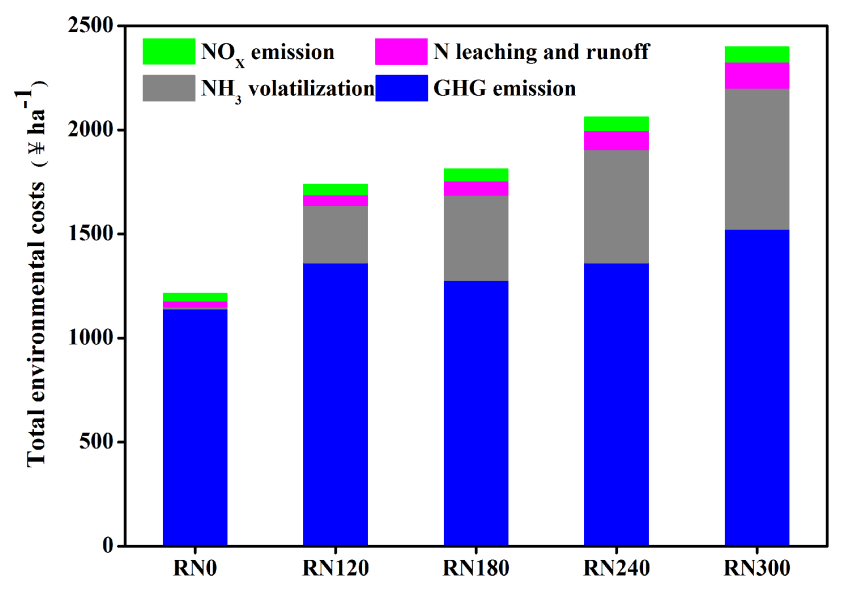

Figure 5. Seasonal average total environmental costs incurred by greenhouse gas (GHG) emissions and reactive $\mathrm{N}(\mathrm{Nr})$ losses for rice production in Taihu Lake region.

(Table 5), and $15.76 \%$ for environmental costs (Table 6). Further reduction in GHG and $\mathrm{Nr}$ releases (especially for $\mathrm{CH}_{4}$ emissions and $\mathrm{NH}_{3}$ volatilization) is possible, with the implementation of knowledge-based managements (Chen et al., 2014; Nayak et al., 2015). For the mitigation of Nr releases, switching the $\mathrm{N}$ fertilizer application method from surface broadcast to deep incorporation could largely lower the $\mathrm{NH}_{3}$ volatilization from paddy soils (Zhang et al., 2012; Li et al., 2014). Moreover, other optimum N managements, such as applying controlled-release fertilizers and urease inhibitors, could also effectively increase the NUE and reduce the overall Nr losses (Chen et al., 2014). For the mitigation of GHG emissions, rather than being directly incorporated before rice transplantation, crop residues should be preferen-

tially decomposed under aerobic conditions or used to produce biochar through pyrolysis, which could effectively reduce $\mathrm{CH}_{4}$ emissions (Linquist et al., 2012; Xie et al., 2013). Moreover, these pre-treatments are also beneficial for carbon sequestration and yield production (Woolf et al., 2010; Linquist et al., 2012).

Most previous studies have merely focused on the quantification of GHG and $\mathrm{Nr}$ releases from food production from the perspective of environment assessments (Zhao et al., 2012b; Ma et al., 2013; Zhao et al., 2015). The perspective of economic evaluation is seldom implemented, which goes against encouraging farmers to participate in the abatement of GHG and $\mathrm{Nr}$ releases on their own initiative (Xia et al., 2014). The current pattern of rice production in the TLR incurs great costs to the environment, accounting for $13.47 \%$ of the net economic return that farmers ultimately acquire (Table 6). Such an evaluation facilitates the translation of highly specialized scientific conclusions into monetary-based information that is more familiar and accessible for farmers, and therefore likely encouraging them to adopt eco-friendly agricultural managements (Wang et al., 2014b). Profitability is generally considered the main driver for farmers to change their management approach. Compared to traditional $\mathrm{N}$ application rate, a reduction of $20 \%$ would make environmental cost savings of $14 \%$, while simultaneously improving the economic return of farmers by CNY $648 \mathrm{ha}^{-1}$ (Table 6). This represents an incentive for farmers to optimize their $\mathrm{N}$ fertilizer application rates, provided that such information is available to them.

Considering the fact that no specific carbon- and $\mathrm{Nr}-$ mitigation incentive programs, like the "Carbon Farming Initiative" in Australia (Lam et al., 2013), have been launched in China, an ecological compensation incentive mechanism should be established by governments. This should be a national subsidy program with a special compensation and award fund to cover the extra mitigation costs induced by the adoption of knowledge-based mitigation managements for farmers (Xia et al., 2016). Such a program would provide farmers with a tangible incentive, thus guiding them towards gradually adopting the mitigation managements, which could effectively curb GHG emissions and $\mathrm{Nr}$ losses but likely exert few positive effects on improving their net economic return (Xia et al., 2014). Examples include the composing of crop straws aerobically, or their use to produce biochar before incorporation (Xie et al., 2013), and encouraging the application of deep placement of $\mathrm{N}$ fertilizer (Wang et al., 2014b), as well as the application of enhanced-efficiency $\mathrm{N}$ fertilizers during the rice-growing season (Akiyama et al., 2010).

\section{Conclusions}

Our results demonstrated that producing rice yield in the TLR released substantial GHG and Nr, which largely at- 
tributed to the current direct straw incorporation and excessive $\mathrm{N}$ fertilizer inputs. $\mathrm{CH}_{4}$ emissions and $\mathrm{NH}_{3}$ volatilization dominated the GHG and $\mathrm{Nr}$ releases, respectively. Reducing $\mathrm{N}$ application rate by $20 \%$ from the tradition level $\left(300 \mathrm{~kg} \mathrm{Nha}^{-1}\right.$ ) could effectively decrease the GHG emissions, $\mathrm{Nr}$ releases and the damage costs to the environment, while increasing the rice yield and improving farmers' income simultaneously. Agricultural managements, such as letting straw decompose aerobically before its incorporation and optimizing the application method of $\mathrm{N}$ fertilizer, showed large potentials to further reduce the GHG (e.g., $\mathrm{CH}_{4}$ emission) and $\mathrm{Nr}$ releases (e.g., $\mathrm{NH}_{3}$ volatilization) from rice production in this region. Further studies are needed to evaluate the comprehensive effects of these managements on GHG emissions, $\mathrm{Nr}$ releases, and farmers' economic returns.

\section{The Supplement related to this article is available online at doi:10.5194/bg-13-4569-2016-supplement.}

Acknowledgements. This study was financially supported by the CAS Strategic Priority Research Program (grant no. XDA05020200) and the National Science and Technology Pillar Program (2013BAD11B00). We gratefully acknowledge the technical assistance provided by the Changshu Agroecological Experimental Station of the Chinese Academy of Sciences.

Edited by: R. Conant

Reviewed by: two anonymous referees

\section{References}

Akiyama, H., Yan, X., and Yagi, K.: Evaluation of effectiveness of enhanced-efficiency fertilizers as mitigation options for $\mathrm{N}_{2} \mathrm{O}$ and $\mathrm{NO}$ emissions from agricultural soils: meta-analysis, Glob. Change Biol., 16, 1837-1846, 2010.

Banger, K., Tian, H., and Lu, C.: Do nitrogen fertilizers stimulate or inhibit methane emissions from rice fields, Glob. Change Biol., 18, 3259-3267, 2012.

Chen, X., Cui, Z., Fan, M., Vitousek, P., Zhao, M., Ma, W., Wang, Z., Zhang, W., Yan, X., and Yang, J.: Producing more grain with lower environmental costs, Nature, 514, 486-489, 2014.

Cheng, K., Yan, M., Nayak, D., Pan, G., Smith, P., Zheng, J., and Zheng, J.: Carbon footprint of crop production in China: an analysis of National Statistics data, J. Agr. Sci., 153, 422-431, 2014.

Cui, Z., Yue, S., Wang, G., Meng, Q., Wu, L., Yang, Z., Zhang, Q., Li, S., Zhang, F., and Chen, X.: Closing the yield gap could reduce projected greenhouse gas emissions: a case study of maize production in China, Glob. Change Biol., 19, 2467-2477, $2013 \mathrm{a}$.

Cui, Z., Yue, S., Wang, G., Zhang, F., and Chen, X.: In-season rootzone $\mathrm{N}$ management for mitigating greenhouse gas emission and reactive $\mathrm{N}$ losses in intensive wheat production, Environ. Sci. Technol., 47, 6015-6022, 2013b.
Cui, Z., Wang, G., Yue, S., Wu, L., Zhang, W., Zhang, F., and Chen, $\mathrm{X}$.: Closing the N-use efficiency gap to achieve food and environmental security, Environ. Sci. Technol., 48, 5780-5787, 2014.

Galloway, J. N., Townsend, A. R., Erisman, J. W., Bekunda, M., Cai, Z., Freney, J. R., Martinelli, L. A., Seitzinger, S. P., and Sutton, M. A.: Transformation of the nitrogen cycle: recent trends, questions, and potential solutions, Science, 320, 889-892, 2008.

Gu, B., Ge, Y., Ren, Y., Xu, B., Luo, W., Jiang, H., Gu, B., and Chang, J.: Atmospheric reactive nitrogen in China: Sources, recent trends, and damage costs, Environ. Sci. Technol., 46, 94209427, 2012.

Huang, T., Gao, B., Christie, P., and Ju, X.: Net global warming potential and greenhouse gas intensity in a double-cropping cereal rotation as affected by nitrogen and straw management, Biogeosciences, 10, 7897-7911, doi:10.5194/bg-10-7897-2013, 2013.

Huang, Y., Zou, J., Zheng, X., Wang, Y., and Xu, X.: Nitrous oxide emissions as influenced by amendment of plant residues with different C: N ratios, Soil Biol. Biochem., 36, 973-981, 2004.

Ju, X., Xing, G., Chen, X., Zhang, S., Zhang, L., Liu, X., Cui, Z., Yin, B., Christie, P., and Zhu, Z.: Reducing environmental risk by improving $\mathrm{N}$ management in intensive Chinese agricultural systems, P. Natl. Acad. Sci. USA, 106, 3041-3046, 2009.

Lam, S. K., Chen, D., Mosier, A. R., and Roush, R.: The potential for carbon sequestration in Australian agricultural soils is technically and economically limited, Sci. Rep., 3, 2179, doi:10.1038/srep02179, 2013.

Li, X., Xia, L., and Yan, X.: Application of membrane inlet mass spectrometry to directly quantify denitrification in flooded rice paddy soil, Biol. Fertil. Soils, 50, 891-900, 2014.

Liang L.: Environmental impact assessment of circular agriculture based on life cycle assessment, Methods and case studies, $\mathrm{PhD}$ thesis, China Agricultural University, 2009 (in Chinese with English abstract).

Linquist, B., Adviento-Borbe, M., Pittelkow, C., van Kessel, C., and van Groenigen, K.: Fertilizer management practices and greenhouse gas emissions from rice systems: A quantitative review and analysis, Field Crop. Res., 135, 10-21, 2012.

Lu, F., Wang, X., Han, B., Ouyang, Z., Duan, X., Zheng, H., and Miao, H.: Soil carbon sequestrations by nitrogen fertilizer application, straw return and no-tillage in China's cropland, Glob. Change Biol., 15, 281-305, 2009.

Ma, J., Ma, E., Xu, H., Yagi, K., and Cai, Z.: Wheat straw management affects $\mathrm{CH}_{4}$ and $\mathrm{N}_{2} \mathrm{O}$ emissions from rice fields, Soil Biol Biochem., 41, 1022-1028, 2009.

Ma, Y., Kong, X., Yang, B., Zhang, X., Yan, X., Yang, J., and Xiong, Z.: Net global warming potential and greenhouse gas intensity of annual rice-wheat rotations with integrated soil-crop system management, Agric. Ecosyst. Environ., 164, 209-219, 2013.

Mandal, B., Majumder, B., Adhya, T., Bandyopadhyay, P., Gangopadhyay, A., Sarkar, D., Kundu, M., Choudhury, S. G., Hazra, G., and Kundu, S.: Potential of double-cropped rice ecology to conserve organic carbon under subtropical climate, Glob. Change Biol., 14, 2139-2151, 2008.

Nayak, D., Saetnan, E., Cheng, K., Wang, W., Koslowski, F., Cheng, Y., Zhu, W. Y., Wang, J., Liu, J., and Moran, D.: Management opportunities to mitigate greenhouse gas emissions from Chinese agriculture, Agric. Ecosyst. Environ., 209, 108-124, 2015.

Qin, Y., Liu, S., Guo, Y., Liu, Q., and Zou, J.: Methane and nitrous oxide emissions from organic and conventional rice crop- 
ping systems in Southeast China, Biol. Fertil. Soils, 46, 825-834, 2010.

Shan, J. and Yan, X. Y.: Effects of crop residue returning on nitrous oxide emissions in agricultural soils, Atmos. Environ., 71, 170$175,2013$.

Shang, Q., Yang, X., Gao, C., Wu, P., Liu, J., Xu, Y., Shen, Q., Zou, J., and Guo, S.: Net annual global warming potential and greenhouse gas intensity in Chinese double rice-cropping systems: a 3year field measurement in long-term fertilizer experiments, Glob. Change Biol., 17, 2196-2210, 2011.

Singh, Y., Singh, B., and Timsina, J.: Crop residue management for nutrient cycling and improving soil productivity in rice-based cropping systems in the tropics, Adv. Agron., 85, 269-407, 2005.

Wang, W., Guo, L., Li, Y., Su, M., Lin, Y., De Perthuis, C., Ju, X., Lin, E., and Moran, D.: Greenhouse gas intensity of three main crops and implications for low-carbon agriculture in China, Climatic Change, 128, 57-70, 2014a.

Wang, W., Koslowski, F., Nayak, D. R., Smith, P., Saetnan, E., Ju, X., Guo, L., Han, G., de Perthuis, C., Lin, E., and Moran, D.: Greenhouse gas mitigation in Chinese agriculture: Distinguishing technical and economic potentials, Global Environ. Change, 26, 53-62, 2014b.

Woolf, D., Amonette, J. E., Street-Perrott, F. A., Lehmann, J., and Joseph, S.: Sustainable biochar to mitigate global climate change, Nat. Commun., 1, 56, doi:10.1038/ncomms1053, 2010.

Xia, L., Wang, S., and Yan, X.: Effects of long-term straw incorporation on the net global warming potential and the net economic benefit in a rice-wheat cropping system in China, Agric. Ecosyst. Environ., 197, 118-127, 2014.

Xia, L., Ti, C., Li, B., Xia, Y., and Yan, X.: Greenhouse gas emissions and reactive nitrogen releases during the life-cycles of staple food production in China and their mitigation potential, Sci. Total Environ., 556, 116-125, 2016.

Xia, Y. and Yan, X.: Life-cycle evaluation of nitrogen-use in rice-farming systems: implications for economically-optimal nitrogen rates, Biogeosciences, 8, 3159-3168, doi:10.5194/bg-83159-2011, 2011.

Xia, Y. and Yan, X.: Ecologically optimal nitrogen application rates for rice cropping in the Taihu Lake region of China, Sustain. Sci., 7, 33-44, 2012

Xie, B., Zheng, X., Zhou, Z., Gu, J., Zhu, B., Chen, X., Shi, Y., Wang, Y., Zhao, Z., and Liu, C.: Effects of nitrogen fertilizer on $\mathrm{CH}_{4}$ emission from rice fields: multi-site field observations, Plant Soil, 326, 393-401, 2010.

Xie, Z., Xu, Y., Liu, G., Liu, Q., Zhu, J., Tu, C., Amonette, J. E., Cadisch, G., Yong, J. W., and Hu, S.: Impact of biochar application on nitrogen nutrition of rice, greenhouse-gas emissions and soil organic carbon dynamics in two paddy soils of China, Plant Soil, 370, 527-540, 2013

Yan, X., Akiyama, H., Yagi, K., and Akimoto, H.: Global estimations of the inventory and mitigation potential of methane emissions from rice cultivation conducted using the 2006 Intergovernmental Panel on Climate Change Guidelines, Global Biogeochem. Cy., 23, GB2002, doi:10.1029/2008GB003299, 2009.
Yan, X., Cai, Z., Wang, S., and Smith, P.: Direct measurement of soil organic carbon content change in the croplands of China, Glob. Change Biol., 17, 1487-1496, 2011.

Yan, X., Ti, C.,Vitousek, P., Chen, D., Leip, A., Cai, Z., and Zhu, Z.: Fertilizer nitrogen recovery efficiencies in crop production systems of China with and without consideration of the residual effect of nitrogen, Environ. Res. Lett., 9, 095002 doi:10.1088/1748-9326/9/9/095002, 2014.

Yao, Z., Zheng, X., Dong, H., Wang, R., Mei, B., and Zhu, J.: A 3year record of $\mathrm{N}_{2} \mathrm{O}$ and $\mathrm{CH}_{4}$ emissions from a sandy loam paddy during rice seasons as affected by different nitrogen application rates, Agric. Ecosyst. Environ., 152, 1-9, 2013.

Zhang, F., Cui, Z., Chen, X., Ju, X., Shen, J., Chen, Q., Liu, X., Zhang, W., Mi, G., and Fan, M.: Integrated nutrient management for food security and environmental quality in China, Adv. Agron., 116, 1-40, 2012.

Zhang, W., Dou, Z., He, P., Ju, X., Powlson, D., Chadwick, D., Norse, D., Lu, Y., Zhang, Y., and Wu, L.: New technologies reduce greenhouse gas emissions from nitrogenous fertilizer in China, P. Natl. Acad. Sci. USA, 110, 8375-8380, 2013.

Zhao, M., Tian, Y., Ma, Y., Zhang, M., Yao, Y., Xiong, Z., Yin, B., and Zhu, Z.: Mitigating gaseous nitrogen emissions intensity from a Chinese rice cropping system through an improved management practice aimed to close the yield gap, Agric. Ecosyst. Environ., 203, 36-45, 2015.

Zhao, X., Zhou, Y., Min, J., Wang, S., Shi, W., and Xing, G.: Nitrogen runoff dominates water nitrogen pollution from rice-wheat rotation in the Taihu Lake region of China, Agric. Ecosyst. Environ., 156, 1-11, 2012a.

Zhao, X., Zhou, Y., Wang, S., Xing, G., Shi, W., Xu, R., and Zhu, Z.: Nitrogen balance in a highly fertilized rice-wheat doublecropping system in southern China, Soil Sci. Soc. Am. J., 76, 1068-1078, 2012b.

Zhao, X., Liu, S. L., Pu, C., Zhang, X. Q., Xue, J. F., Zhang, R., Wang, Y. Q., Lal, R., Zhang, H. L., and Chen, F.: Methane and nitrous oxide emissions under no-till farming in China: a metaanalysis, Glob. Change Biol., 22, 1372-1384, 2015a.

Zhao, X., Zhang, R., Xue, J. F., Pu, C., Zhang, X. Q., Liu, S. L., Chen, F., Lal, R., and Zhang, H. L.: Management-induced changes to soil organic carbon in China: A meta-analysis, Adv. Agron., 134, 1-49, 2015b.

Zou, J., Huang, Y., Jiang, J., Zheng, X., and Sass, R. L.: A 3-year field measurement of methane and nitrous oxide emissions from rice paddies in China: Effects of water regime, crop residue, and fertilizer application, Global Biogeochem. Cy., 19, GB2021, doi:10.1029/2004GB002401, 2005. 